\title{
WestVirginiaUniversity
}

THE RESEARCH REPOSITORY @ WVU

West Virginia Agricultural and Forestry Experiment

Davis College of Agriculture, Natural Resources

Station Bulletins

And Design

$1-1-1926$

\section{Tomato Late Blight and its Relation to Late Blight of Potato}

Anthony Berg

Follow this and additional works at: https://researchrepository.wvu.edu/ wv_agricultural_and_forestry_experiment_station_bulletins

\section{Digital Commons Citation}

Berg, Anthony, "Tomato Late Blight and its Relation to Late Blight of Potato" (1926). West Virginia Agricultural and Forestry Experiment Station Bulletins. 205.

https://researchrepository.wvu.edu/wv_agricultural_and_forestry_experiment_station_bulletins/205 @ WVU. It has been accepted for inclusion in West Virginia Agricultural and Forestry Experiment Station Bulletins by an authorized administrator of The Research Repository@WVU. For more information, please contact ian.harmon@mail.wvu.edu. 
West Virginia University Libraries 
EVANSDALE LIBRARY WEST VRGINIA UNVERSTY 
Restricted

Circulation Only

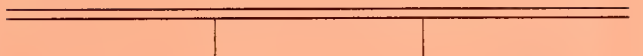





\title{
Aquricultural Experiment Statín
}

College of Agriculture, reategt Birginia Anibersity

\author{
HENRY G. KNIGHT, Director
}

Morgantown

\section{Tomato Late Blight and Its Relation to Late Blight of Potato (Technical)}

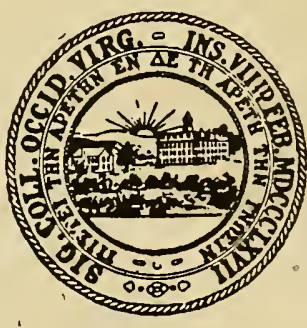

By

ANTHONY BERG 


\section{AGRICULTURAL EXPERIMENT STATION STAFF}

FRANK BUTLER TROTTER, A. M., LL. D. -_..._President of the University HENRY G. KNIGHT, Ph. D.._._._._Dean of the College of Agriculture and Director of the Experiment Station

WALTER C. SCHNOPP, B. S. Agr Agricultural Editor JOHN C. JOHNSTON Chief Clerk

\section{AGRONOMY}

R. J. Garber, Ph. D.

T. E. Odland, Ph. D. Associate Agronomist

D. R. Dodd, M. S. Assistant Agronomist

T. C. Mcllvaine, $\mathrm{Ph} . \mathrm{D} \cdot{ }^{* \dagger}$

M. M. Hoover, M. S. Assistant Agronomist

H. K. Rowley, B. S. Agr.**

ANIMAL HUSBANDRY

Seed Analyst

F. A. Livesay, M. S.

Animal Husbandman

Chas. V. Wilson, M. S.

Assistant Animal Husbandman

E. C. Stilwell, M. S.

Assistant Animal Husbandman

R. H. Tuckwiller, B. S. Agr.*

Assistant Animal Husbandman

CHEMISTRY

R. B. Dustman, $\mathrm{Ph}$. D.

Associate Chemist

Chas. E. Weakley, Ji',, B. A.

T. B. Leith, B. A.**

Assistant Chemist

T. J. Cochrane, M. S.

Assistant Chemist

Paul Daughenbaugh

Junior Chemis: Assistant in Chemistry

DAIRY HUSBANDRY

E. L. Anthony, M. S. Agr.

Dairy Husbandman

I. O. Henderson, M. S. Agr.

Associate Dairy Husbandmai

G. Malcolm Trout, M. S.

Junior Dairy Husbandma»

\section{EENTOMOLOGY}

IL. M. Peairs, Ph. D.

W. E. Rumsey, B. S.**

Entomologisı

T. E. Dills, B. S.**

State Entomologin:

Assistant in Entomolog;

ZOOLOGY

IF. E. Chidester, Ph. D.
FARM ECONOMICS

A. J. Dadisman, $\mathrm{Ph}$. D.

Paul A. Eke, Ph. D.

Farm Economist

Assistant Farm Economist

F. D. Cornell, Jr., M. S.

Junior Farm Mechanician W. W. Armentrout, M. S.

Junior Farm Economist

HOME ECONOMICS

Ruth Buchanan, Ph. D.

Nell Nesbitt, A. M.

Home Economist

Home Management Specialist

HORTICULTURE

H. L. Crane, M. S. Agr.

Horticulturist

Associate Horticulturist

H. E. Knowlton, Ph. D.

Associate Horticulturist

K. C. Westover, M. S. Agr.

Assistant Horticulturist

Ernest Angelo, M. S. Agr.

Junior Horticulturist

L. F. Sutton, B. S. Agr.

Assistant Horticulturist

H. P. Sevy, B. S. Agr.

Assistant in Horticulture

i. L. Tener, B. S.

Assistant in Horticulture

PLANT PATHOLOGY

N. J. Giddings, Ph. D.

Plant Pathologist

Anthony Berg, M. S.

Assistant Plant Pathologist

L. H. Leonian, $\mathrm{Ph}$. D.

Assistant Plant Pathologist

E. C. Sherwood, M. S.

Assistant Plant Pathologist

POULTRY HUSBANDRY

Horace Atwood, M. S. Agr.

Poultry Husbandman

E. P. Deatrick, Ph. D.

SOILS

Associate Suil Teclinologist

T. L. Harris, Ph. D.

RURAL SOCIOLOGY

Zoologist

Sociologist

- In cooperation with the U. S. Department of Agriculture, Washlngton, D. C.

* In cooperatiou with the State Department of Agrlculture, Charleston, W. Va.

$\rightarrow$ In charge of the Lakin Sub-Station, Lakin, w. Va.

tIn charge of the Reymann Memorial Farms, Wardensville, W. Va. 


\section{Tomato Late Blight And Its Relation To Late Blight of Potato}

The fungus Phytophthora infestans (Mont. De Bary) has been the subject of so many investigations and controversies that it fills one of the most romantic chapter's in the history of biological research. Most of these investigations deal with late blight of potatoes, tuber rot, and the much disputed subject of oospore formation.

A review of this phase of the problem is neither necessary nor desirable, as it has been covered repeatedly and adequately by others.

The relation of late blight of tomato to the late blight of potato has always becn very much in question. This investigation was undertaken with the object of determining further facts regarding the possible relationship of these two diseases.

\section{HISTORICAL SUMMARY}

The occurrence of tomato late blight, caused by Phytophthora infestans, was recorded in the literature by Payen (23) as early as 1848. Numerous references, to this disease, can be found in the early plant disease literature of Europe.

The first record of the disease in America is perhaps that of Thaxter (33) in which he stated: "For some reason not readily explained, tomatoes in various localities have, during the latter portion of last season, been greatly injured by the attack of various fungi, which in 1889 did no special damage to the crop. The most noticeable injury was done by the fungus of the potato rot, ( $P$. infestans) which not only attacked the leaves so as to do considerable damage, but appeared with virulence upon green and even partly ripe fruit. ... Should this taste for tomatoes be perpetuated, it will be necessary to resort to Bordeaux mixture, or carbonate of copper in order to save the September crop. It is unlikely, however, that it will be permanently serious."

Most of the early observers believed that this fungus passed readily from potatoes to tomatoes. W. C. Sturgiss (32) referring to $P$. infestans stated: "The fungus which does so much damage to potatoes frequently attacks tomatoes also. Its general effect is the same in both cases, and it may be controlled by the same means." Stone (30) said: "Downy mildew of tomato is rarely seen in Massachusetts. It is caused by the same fungus which is responsible for the well-known blight of potatoes." 
In a later report by Stone (31) he stated: "Damp and rainy weather following a prolonged dry season caused an unusual outbreak on tomato plants, namely downy mildew, which is the same as that giving rise to the late blight of potatoes." In California, R. E. Smith (27), referring to the late blight of tomatoes, stated: "This trouble proved to be a common disease of another plant, which sometimes attacks the tomato, but very seldom, as serious as this. It is the potato blight or mildew, well-known to every eastern potato grower. . . . The cause is a parasitic fungus, Phytophthora infestans."

In describing late blight of tomato, McAlpine (19) stated: "It is exactly the same fungus in the tomato as that causing potato blight, and this was proved conclusively by infecting a healthy potato with the spores of the fungus from diseased tomato, and a healthy tomato was infected with the spores of Irish blight, obtained from one of the diseased potatoes grown in Beech forest."

Many similar statements can be found in the literature.

\section{GEOGRAPHICAL DISTRIBUTION}

Tomato late blight, caused by $P$. infestans, has been reported from every continent except Africa. It is found in both hemispheres and can be traced in a continuous belt around the globe. In the United States, only a few records of its appearance in the northern states are found, although it was first observed in Connecticut. It has also been reported as occurring in Maine (33). The disease occurs almost annually in the higher altitudes of Virginia, West Virginia, and North Carolina, (13). In Central America it has been reported from Mexico (16), Jamaica (2), and Porto Rico (34); and in South America from Uruguay (11). In Europe it has been reported from England (24), Belgium (17), Germany (1), Italy (3), and from practically every country on the continent. E. J. Butler (6) in a report of its occurrence in India wrote: "P. infestans was found attacking potatoes and tomatoes at Jorbat, in Assam," and he expressed the fear that this fungus was developing a race which would be able to withstand the heat of the plains. It has been repeatedly reported from Australia and New Zealand, and from the Islands of Mauritius (29) and Hawaii (7).

\section{ECONOMIC IMPORTANCE}

The economic importance of this disease is considerably minimized by the fact that it does not occur in the most important commercial tomato growing districts. On the other hand, there are certain sections in the higher altitudes of Virginia and West Virginia well adapted for tomato growing, in which it is practically impossible to grow a sufficient 
supply for table use, without careful and persistent spraying. Large damage to the late erop has been reported from southern California by Smith (27). Again, we find a record in the Journal of the Board of Agriculture, England (19), where a grower lost fifty tons of a total of seventy tons, or 71 per cent of the crop. Considerable losses to the tomato erop have been reported from South Australia and New Zealand. It also has been reported as doing eonsiderable damage to the tomato crop in Porto Rico (34).

\section{THE DISEASE}

The leaves, the stems, and the fruit are affected.

On the leaves and the petioles.-The infection on the foliage is so similar to the characteristic lesions of the late blight of potato that a detailed description is unnecessary. The petioles are readily attacked, and as a consequence the affected leaves often droop.

On the stem.-The disease progresses very rapidly on the tender portions of the stem, while on the older and woody parts the infection advances slowly and the lesions are much darker.

On the fruits.-The grieen fruits are most susceptible to the attack of the disease, although partly ripened fruit may also be infected. Most of these infections are found around the stem-end, or where two fruits come in contact with each other or with the ground. It has been demonstrated, however, that the fungus can enter through the unruptured epidermis at any point.

The first symptoms consist of irregular brown patches which at first do not extend much beyond the epidermal layer. When the concitions are more favorable, the lesions spread rapidly, and form more or less concentric zones as they advance. The infected tissues are at first firm, but they soon beeome soft because of the invasion of secondary organisms.

\section{EXPERIMENTS BY OTHER INVESTIGATORS}

The fact that tomato late blight rarely, if ever, appears in eertain sections where potato blight is a destructive disease almost annually, has led to several investigations to determine the identity of the two diseases.

Reed (26) condueted experiments in Virginia, in 1911 and 1912, in which potatoes and tomatoes were planted in alternate hills. "No results were obtained in 1911; in 1912 late blight appeared on both potato and tomato on August 12." He says: "It was found possible to infect potatoes and tomatoes with the blight by taking spores from either host plant." He also states: "In making an inspection of the 
diseased areas, it was found that the tomato blight was always more severe in the vicinity of potato vines. We are led to conclude, therefore, that the Phytophthora of the tomato is identical with that of the potato." He explains the apparent immunity of the potato crop in Virginia by the fact that a large percentage of the potatoes are planted early and consequently have made their growth before the late blight makes its appearance.

McAlpine (21) descirbes a similar experiment in Australia. Tomatotes and potatoes were planted in alternate rows, and his report on the experiment follows: "A row of tomatoes, containing about 150 vines, was planteo alongside potatoes in the Yannathan district, the seed potatoes and the young tomato plants being planted at the same time, on December 27, 1910. About March 11 the potato tops began to show signs of disease, and in about a week they all collapsed with Irish blight. A few days after the potato plants had succumbed, the disease was noticed in the tomatoes when the fruit was forming. When I examined the plot on April 6 not a single plant had escaped, and only an occasional ripe and healthy tomato could be found, and it was evident that the tomatoes had been infected from the adjoining potatoes.",

Wiltshire (35) conducted a series of cross inoculation experiments in 1915. Cut shoots of potatoes and tomatoes were inoculated with a spore suspension and the plants were placed under bell jars. The following are his results:

Spores from potato on potato gave 42 plants infected out of 123 , or 34 per cent infection. used.

Spores from potato on tomato gave no infection on 143 plants

Spores from tomatoes on potatoes gave 4 plants infected out of 107 used, or 3 percent infection.

Spores from tomatoes on tomatoes gave 43 plants infected out of 116 , or 37 per cent infection.

In another series: "Spores from tomatoes on tomato ( 2 plants) heavily infected."

"Spores from potatoes on tomato (2 plants) no infection."

Wiltshire concludes that these results suggest that the Phytophthora infestans attacking potatoes is of a different physiological strain from that attacking tomatoes.

Giddings, N. J., and Anthony Berg (10) conducted cross inoculation experiments with strains of the fungus isolated from tomatoes and potatoes. The results showed that the fungus would pass from one host to the other. However, the potato fungus, when inoculated on the 
tomato produced only small irregular lesions on the tomato leaves. These spots were confined mostly to the lower leaves. Stem lesions did not ocenr in any case. The tomato strain when inoculated on tomato plants produced typical late blight infections on both leaves and stems, and the plants died down in a short time. Both the potato and the tomato strains produced typical disease lesions when inoculated on potato plants, but the tomato strain was less virulent in its attack.

Melhus. I. E. (22) apparently working with a potato strain only, summarizes the results of his experiment as follows:

"Tomato foliage is readily infected with Phytophthor infestrns of the Irish potato, but it has not been possible to infect the fruit except through the peduncles, the calyx, or epidermis. when ruptured. Indeed when the epidermis of the fruit is intact, infection does not take place. The period of inoculation is the same for the tomato and potato, that is, six days, depending on moisture and temperature conditions. The fungus spreads and fruits more sparingly on the foliage of the tomato than on the foliage of susceptible varieties of potato and to this fact are doubtless dne the numerous contradictory statements relative to the identity of species of Phytophthora on these two plants."

\section{CULTURES AND EXPERIMENTAL METHODS}

Numerous inoculations were made during the last five years. In the first experiment, strains of $P$. infestans isolated from potatoes were obtained from Maine, Wisconsin, and West Virginia. The tomato strains were isolated from diseased tomato fruits collected from various parts of West Virginia. Potato and tomato strains from various parts of the world have been added to this collection. The object was to collect strains for comparative study, from every country in which the fungus had been reported. This has proved to be a slow and tedious venture, although the collection is slowly increasing. We have at the present time, in addition to our native strains, potato strains from Bermuda, England, Holland, and Australia, and a tomato strain from Australia.

\section{Methods of Collecting Material for Isolation}

The following method has been found very satisfactory for trans: porting diseased material to the laboratory for isolation, especially where the material has to be in transit for some time. A clean potato tuber is eut into halves, the diseased leaf or stem is placed between the iwo halves and the pieces are firmly tied together with a string. Whe using parts of stems, it is best to holllow out one of the pieces of potato sufficiently to allow the halves to come firmly together after the material has been inserted. The fungus readily passes into the potato tissue 
within twenty-four to forty-eight hours. At the laboratory the halves are separated, the diseased leaf or stem tissue is discarded and the tuber is put into a moist culture dish and placed in a low temperature incubator at about $15^{\circ} \mathrm{C}$. If the material has been in transit for several days, especially in warm weather, Fusarium and other rot fungi may appear on the cut surface of the tuber. These should be removed carefully with a knife before placing the tuber in the culture dish. Tufts of $P$. infestans mycelium usually make their appearance within four or five days. The fungus is then transferred to a potato tuber prepared as follows: A healthy tuber is soaked in a $1: 1,000$ solution of mercuric bichloried for one hour and rinsed in distilled water. A band is peeled off in the direction of the long axis of the tuber. The tuber is then cut into equal halves with a sterile knife, and placed in a moist culture dish. Numerous stabs are made into the cut surface with the point of a sterile knife, tufts of mycelium are inserted into these stabs with a platinum needle. A pure culture can readily be obtained from these, as $P$. infestans on raw potato tissue will outgrow accompanying bacteria and fungi at temperatures of $16-18^{\circ} \mathrm{C}$.

In preparing material for inoculation work the fungus was grown on potato tubers prepared as described above. The fungus covers the entire cut surface of a potato tuber in five or six days when grown at $20^{\circ} \mathrm{C}$. The sporangia were then removed by directing a spray from an atomizer parallel to the cut surface of the tuber. By this method a rich suspension of sporangia comparatively free from mycelial masses can be obtained. The inoculum was applied with an atomizer, and the plants were placed in a moist chamber at around $18^{\circ} \mathrm{C}$. for twentyfour hours unless otherwise stated.

\section{Inoculation Experiments}

The following series of inoculation experiments were made over a period of five years. A large number of strains were used. Some were used for one inoculation test only and then discarded, others were used for a longer period. For the sake of simplicity, the strains used in the experiments are numbered in consecutive order. The letter " $\mathrm{P}$ ", or " $\mathrm{T}$ " is placed after the number to designate potato or tomato strains.

Series 1 -On Tomatoes. Three sets of tomato plants, each consisting of ten plants were inoculated with strains $1 \mathrm{P}, 2 \mathrm{P}$, and $3 \mathrm{~T}$. The fir'st signs of infection became visible three days after the inoculation. The infected plants were then returned to the moist chamber to study the progress of the disease lesions produced by the different strains. All plants inoculated with strain $3 \mathrm{~T}$ developed leaf, stem, and petiole infections, such as occur under natural conditions in the field. Every 


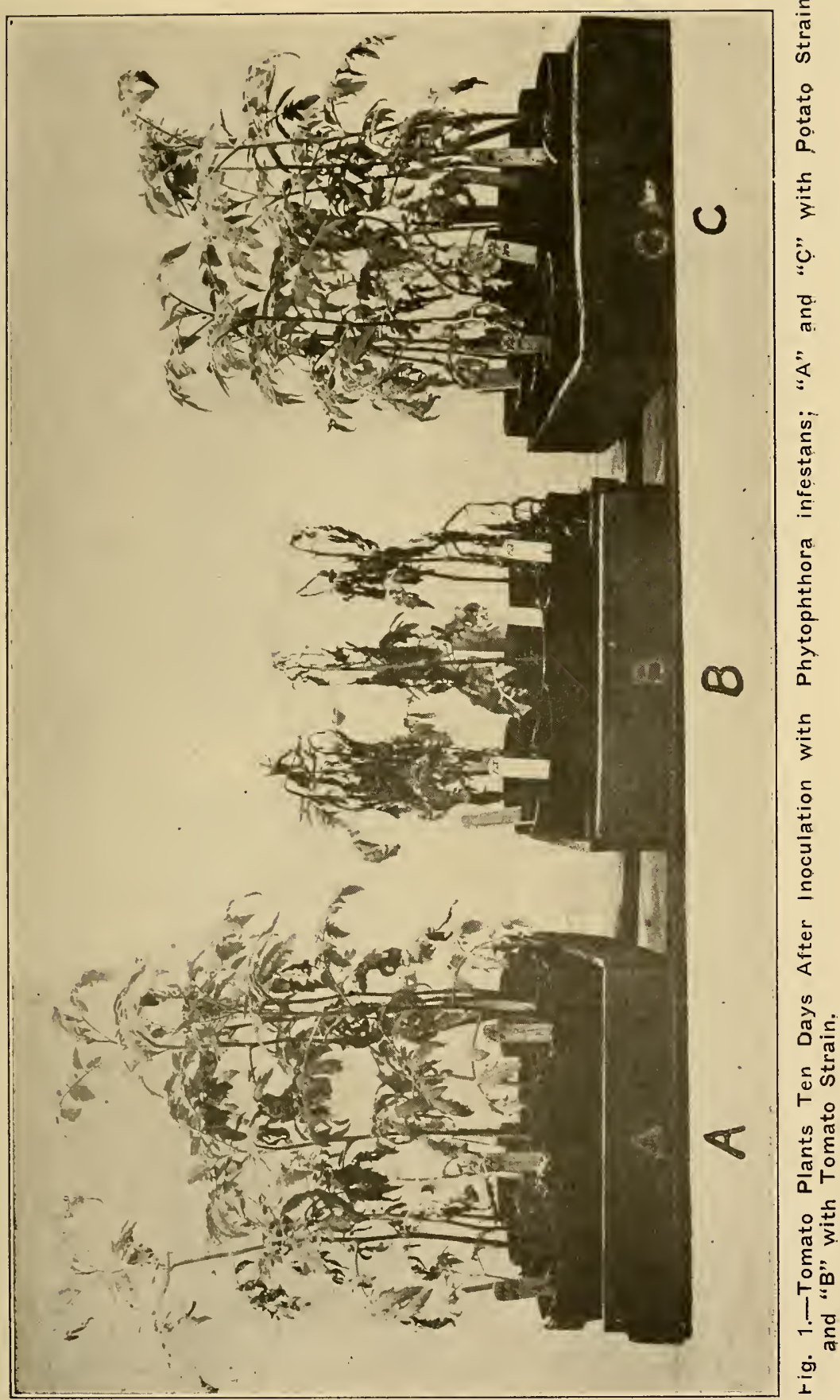




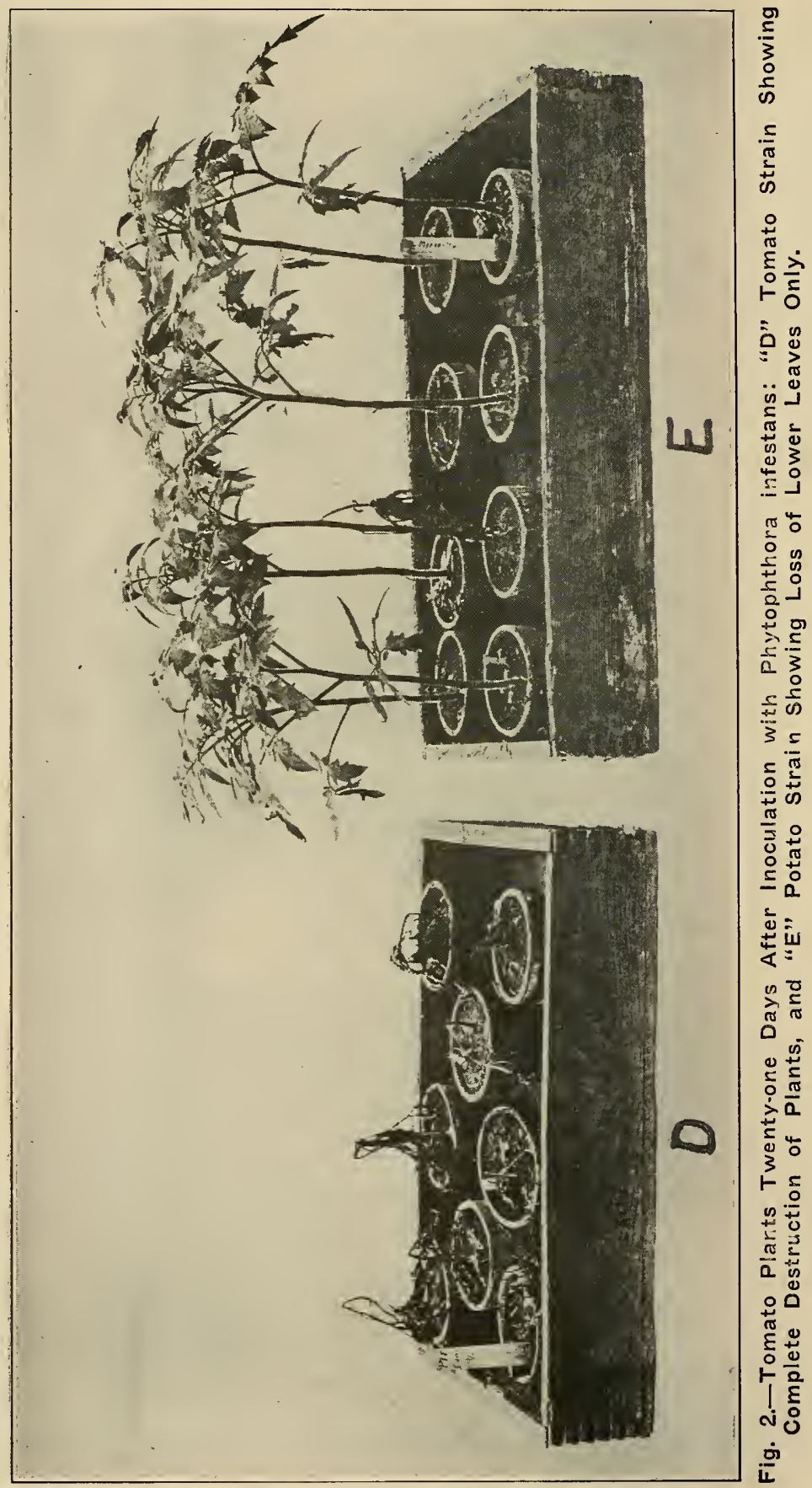


plant suceumbed to the disease in ten days (See Figure 1). The tomato plants inoculated with strains $1 \mathrm{P}$ and $2 \mathrm{P}$, although showing a much greater number of foliage infections did not have a single petiole or stem lesion. The foliage infections were confined mostly to the older leares and did not present the appearance of typical late blight lesions, but were blotches with irregular margins and did not exceed one-fourth of an inch in diameter. (See Figure 3). They attained their maximum size four or five days after the infertion became visible. The lower leaves soon dropped off and the plants fully recovered (See Figure 2).

Series 1-On Potatoes. Three sets of potato plants, each consisting of ten plants, were similarly inoculated with strains $1 \mathrm{P}, 2 \mathrm{P}$, and $3 \mathrm{~T}$. The first signs of infection were noted in about three days after inoculation. All plants became infected. The disease ploduced by the tomato strain, $3 \mathrm{~T}$, although having the appearance of typical blight lesions, did not progress with the same vigor as that produced by the potato strains, $1 \mathrm{P}$ and $2 \mathrm{P}$. This was especially noticeable in the case of stem infections (See Figure 4 ).

The sources of the strains used were as follows:

$1 \mathrm{P}$ - Potato Strain from Morgantown, West Virginia.

$2 \mathrm{P}$-Potato Strain from Maine.

3T-Tomato Strain from Morgantown, West Virginia.

Series 2. This series was an exact duplication of Series 1, with identical final results. A description is, therefore, deemed unnecessary. A tomato plant inoculated with a tomato strain and a tomato plant inoculated with a potato strain were placed under moist bell jars to study the progress of the disease lesions. The lesion produced by the tomato strain progressed very rapidly and produced sporangia profusely on both surfaces of the leaf. The spots produced by the potato strain attained their maximum size within two or three days after infection first became visible, and produced sporangia only very sparingly.

Series 3. Tomato and potato plants were inoculated similarly as in Series 1 and 2, with the exception that a potato strain of $P$. infestans obtained from Wisconsin was substituted for the Maine potato strains. Late blight does not appear on tomatoes in Wisconsin and seldom, if ever, in Maine. The primary object of this inoculation experiment was to compare strains of $P$. infestans from widely separated geographical regions, especially from regions in which late blight does not appear on the tomatoes. The results were similar to those described in Series 1.

Series 4. Three tomato strains isolated from leaf, stem, and fruit respectiveiy, were used in this inoculation experiment to test fo. 


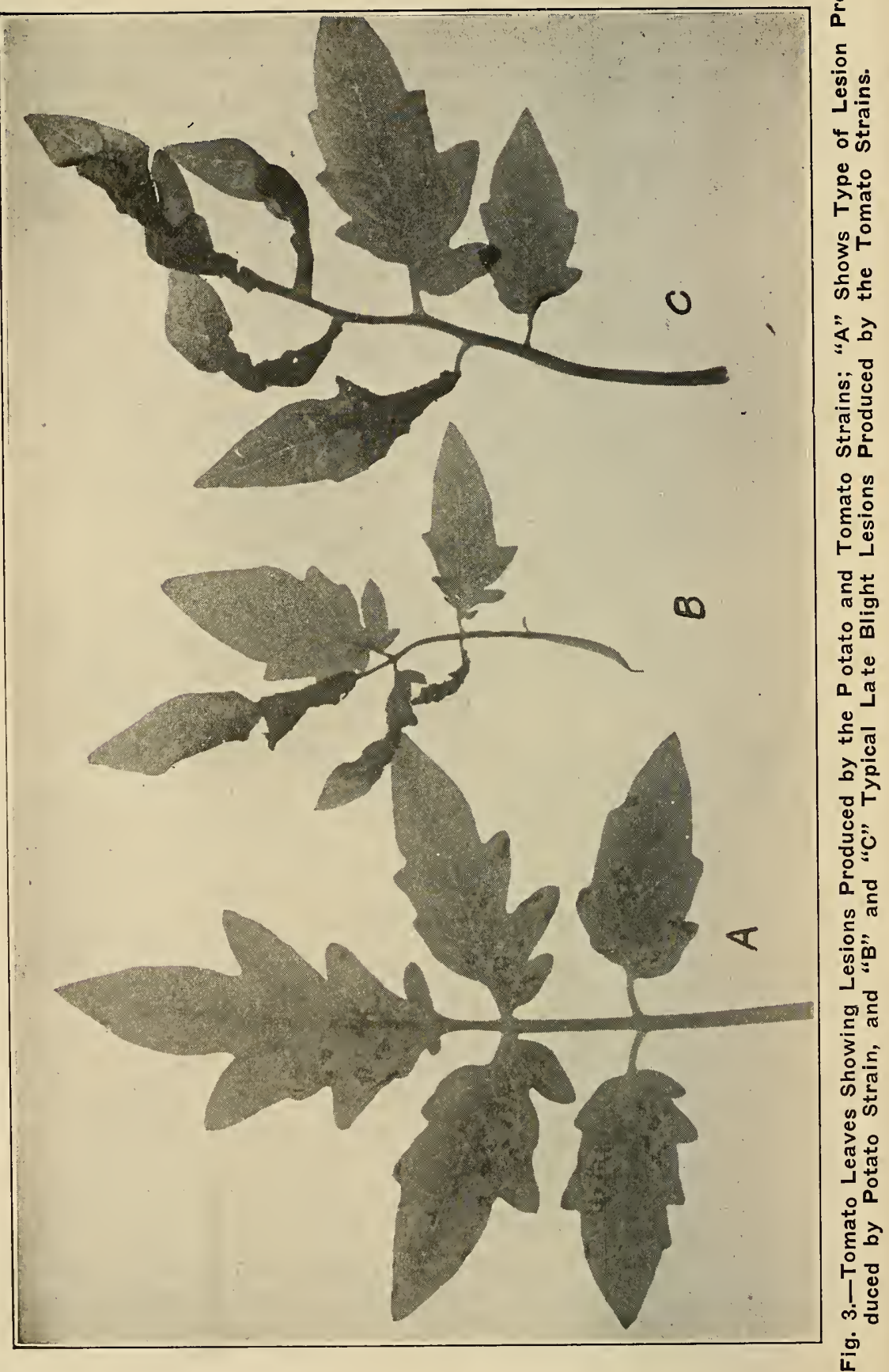




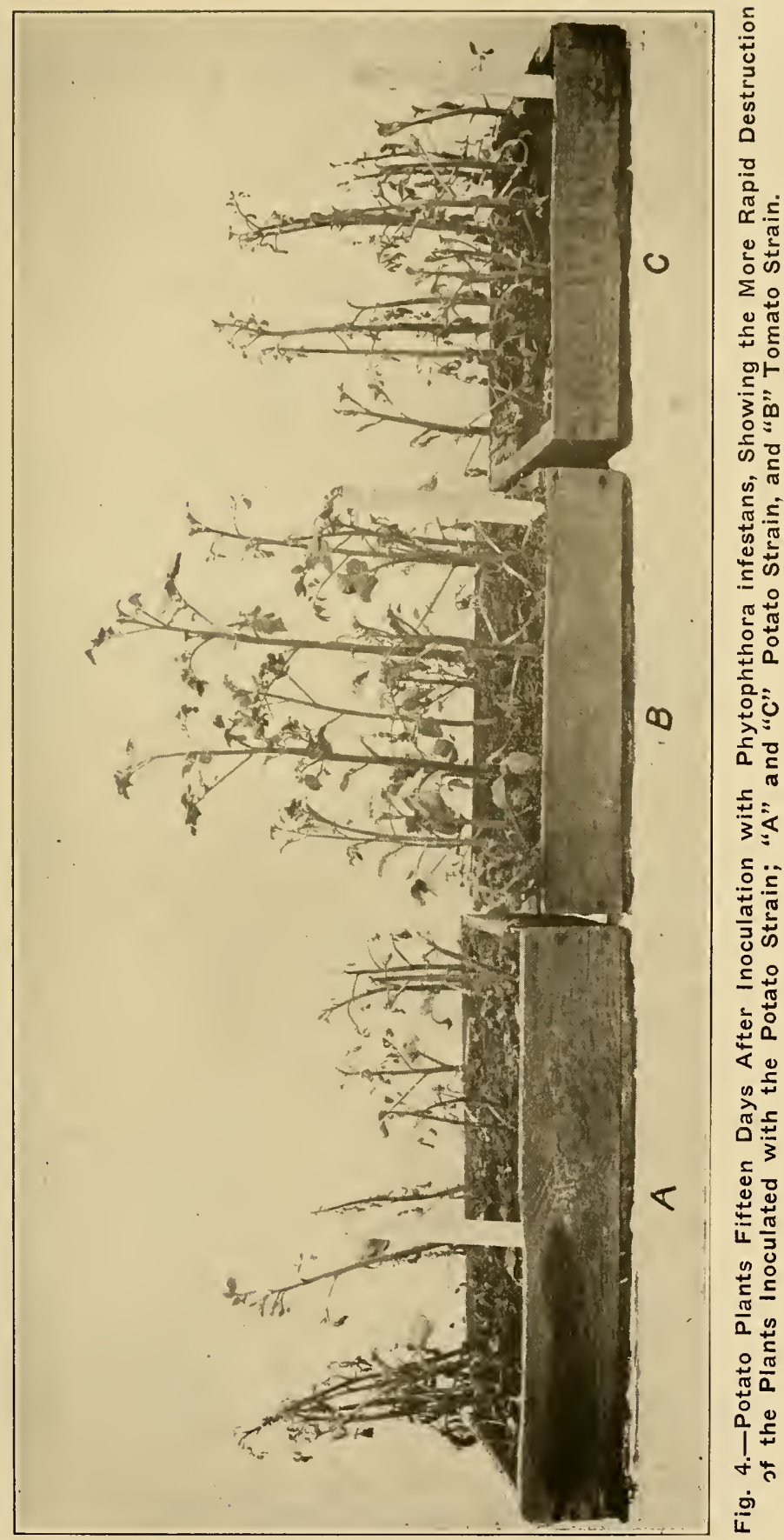


any possible adaptation of the fungus on the various plant members. The results in the accompanying table show that such a specialization did not occur. Plants were also inoculated with a potato strain recently received from Australia, and a West Virginia potato strain for general comparison. The Australian potato strain, when inoculated on tomato, produced the same type of spots as the West Virginia potato strain, and they were similarly confined almost entirely to the lower foliage.

\section{TABLE 1.-Inoculation of Potato Plants with Tomato and Potato Strains.}

\begin{tabular}{|c|c|c|c|c|c|}
\hline Strain Used & $4 \mathrm{~T}$ & $5 \mathrm{~T}$ & $6 \mathbf{T}$ & $7 P$ & $8 \mathrm{P}$ \\
\hline Number of POTATO plants & 10 & 10 & 10 & 11 & 12 \\
\hline Number of Stems & 16 & 13 & 14 & 16 & 13 \\
\hline Number of Plants Infected & 10 & 9 & 11 & 11 & 12 \\
\hline Stems with Stem Lesions & 16 & 4 & 4 & 4 & 10 \\
\hline
\end{tabular}

TABLE 2.-Inoculation of Tomato Plants with Potato and Tomato Strains.

\begin{tabular}{l|c|c|c|c|c}
\hline \hline Strain Used & $5 \mathrm{~T}$ & $6 \mathrm{~T}$ & $7 \mathrm{P}$ & $8 \mathrm{P}$ \\
Number of TOMATO Plants.--- & 10 & 10 & 10 & 10 & 10 \\
Number of Plants Infected.----- & $10^{*}$ & $10^{*}$ & $10^{*}$ & $10 \dagger$ & $10 \dagger$ \\
Plants with Stem Lesions...--- & 10 & 10 & 10 & 0 & 0 \\
\hline
\end{tabular}

(*) Typical Late Blight lesions on foliage and stems.

(†) Numerous small lesions on lower leaves.

The sources of the strains used in this series were as follows:

$4 \mathrm{~T}$-Tomato strain isolated from diseased fruit, Morgantown, West Virginia.

$5 \mathrm{~T}$-Tomato strain isolated from diseased leaf, Morgantown, West Virginia.

6T-Tomato strain isolated from diseased stem, Morgantown, West Virginia.

$7 \mathrm{P}$-Potato strain, tuber isolation from Australia.

8P-Potato strain, leaf isolation from Morgantown, West Virginia.

Series 5. The object of this series was to test the probable effect of different climatic conditions brought about by variations in altitude.

TABLE 3.-Inoculations with Tomato and Potato Strains from Different Altitudes.

\begin{tabular}{ll|l|l|l|l}
\hline \hline Strain Used & $10 \mathrm{~T}$ & $11 \mathrm{~T}$ & $12 \mathrm{P}$ \\
Number of TOMATO plants & $8 \mathrm{~T}$ & 10 & 8 & 8 \\
Number of Plants Infected & 8 & 8 & $8 *$ & $8 *$ & $8 \dagger$ \\
Plants with Stem Lesions & 8 & 8 & 8 & 0 \\
\hline
\end{tabular}

(*) Typical late blight lesions on stems and foliage.

$(\dagger)$ Numerous small spots on lower leaves. 


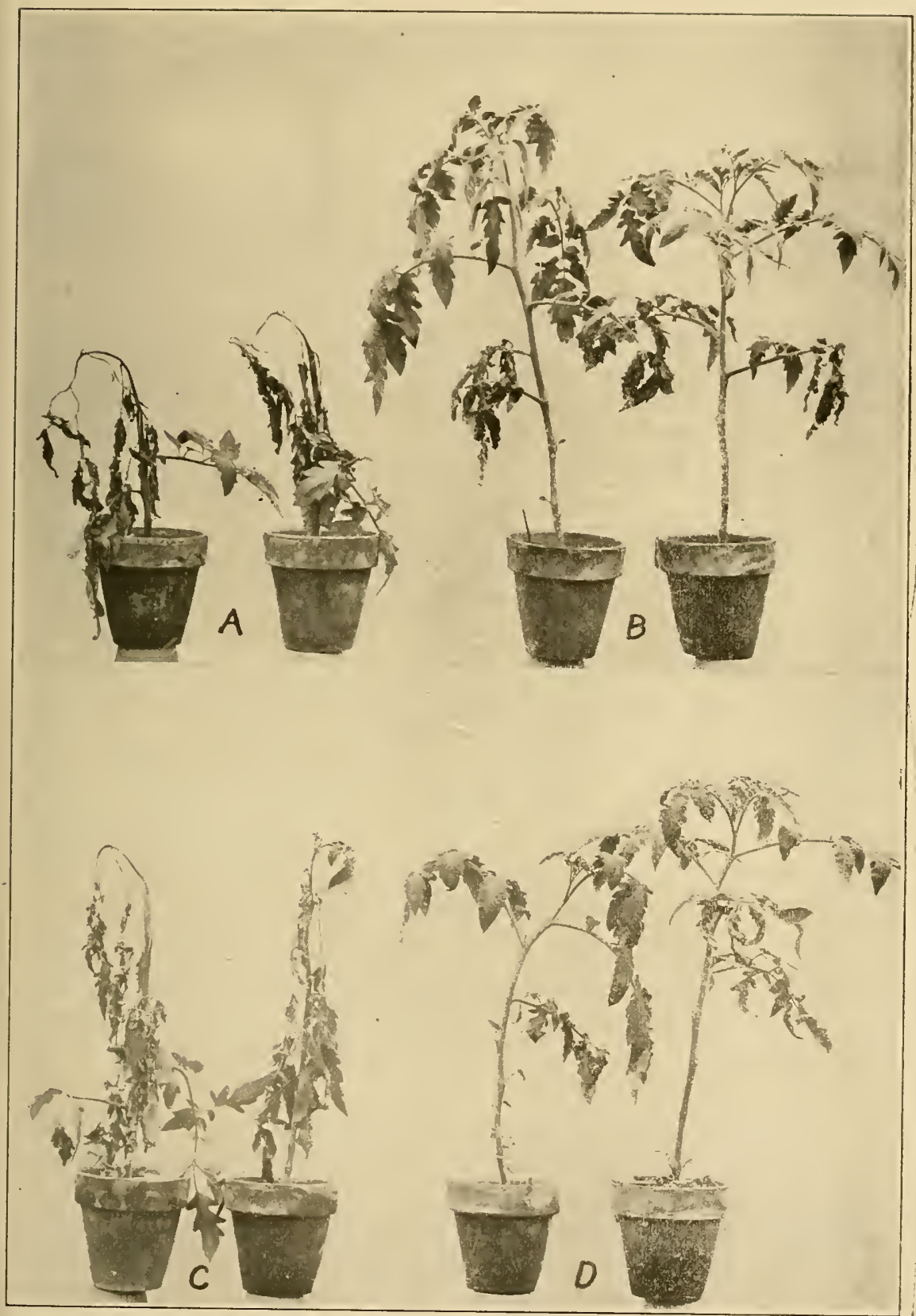

Fig. 5.-Tomato Plants Fifteen Days After Inoculation with Tomato and Potato Strains of Phytophthora infestans. "A," Tomato Strain from West Virginia. "B," Potato Strain from West Virginia.. "C,", Tomato Strain from Australia. "D," Potato Strain from Australia. 
The sources of the strains and the altitudes were as follows:

9T-Tomato strain isolated from Davis, West Virginia, altitude 3,300 feet.

10T-Tomato strain isolated from Montrose, West Virginia, altitude 1,600 feet.

11T-Tomato strain isolated from Morgantown, West Virginia, altitude 1,000 feet.

$12 \mathrm{P}$-Potato strain isolated from Morgantown, West Virginia, altitude 1,000 feet.

The climate of Davis, West Virginia, is cool and the seasons are not unlike those of the northern states where late blight of potato occurs almost every year, but tomato late blight has never been known to occur. Destructive outbreaks of late blight of tomatoes have been repeatedly observed at high altitudes. It would, therefore, seem that scme factor's aside from climatic conditions are responsible for the absence of tomato late blight in some of our northern states. It may be possible that the tomato fungus living on a plant that dies completely in the autumn is dependent on hibernation in the soil, whereas the potato strain is carried over, at least in part, through diseased tubers. It is therefore quite probable that the tomato fungus cannot survive the cold winters of the north, while in the regions of milder winters, it may live over in the soil at lower altitudes and then gradually spread to the adjacent higher altitudes as the season advances. The results of this inoculation experiment would tend to indicate that other factors than climatic conditions are involved in this peculiar stiuation. Potato strains obtained from these altitudes did not produce typical late blight infections when inoculated on tomato plants.

Series 6. A third host plant of $P$. infestans, Solanum aviculare, was introduced into this series. It was hoped that by this means a further differentiation of the two strains might be obtained. Solanum aviculare is an Australian plant and has been reported as being very susceptible to infection by $P$. infestans.

The plants were interplanted with tomatoes and potatoes in the pathological garden where the tomato and potato plants have annually suffered from the natural infections of the fungus. The potato and tomato plants became heavily infected during August and September. The "kangaroo apples" (Solanum aviculare) also became infected, however, to a much less degree than either of the other two host plants. Isolations were made from three of the infected plants during the season. The cultures were marked "?" pending a definite determination of strain by artificial inoculations. The results of the inoculation shown in 
Table + indicate that Solanum aviculare is susceptible to infection by both strains of the fungus under natural conditions.

TABLE 4.-Inoculations with Strains Isolated from Solanum aviculare and Tomato Fruit.

\begin{tabular}{|c|c|c|c|c|}
\hline Strain Used & $13 ?^{*}$ & $14 ?^{* *}$ & $15 ? \div$ & $16 \mathrm{~T} ? f$ \\
\hline Number of TOMATO Plants .. & 12 & 12 & 12 & 12 \\
\hline Number of Plants Infected & 12 & 12 & 12 & 12 \\
\hline Plants with Stem Lesions & 0 & 12 & 0 & 0 \\
\hline
\end{tabular}

- Isolated from Solanum ariculare proved to be a potato strain.

* Isolated from solanum aviculare proved to be a tomato strain.

†Isolated from Solanum aticulare proved to be a potato strain.

†Isolated from tomato fruit proved to be a potato strain.

Both tomatoes and potatoes were badly blighted at the time isolations were made. Strain $16 \mathrm{~T}$ was isolated from a disease lesion of a tomato fruit.

Tomato firuits infected with the potato strain are occasionally found where tomato plants are intermingled with heavily infected potato plants. It is rery probable that such infection takes place through a rupture in the epidermis of the tomato fruit. This may in part account for the reports of sporadic occurrence of tomato blight in certain regions.

Series 7.-One set of thirty-five plants of kangaroo apples (Solanum ariculare) were inoculated with potato strain $12 \mathrm{P}$, and a similar lot of thirty-fire plants were inoculated with tomato strain $9 \mathrm{~T}$. The first signs of infection were visible in four dars. All plants were heavily infected, both on the foliage and on the young shoots. There appeared to be no difference in the susceptibility of Solanum aviculare to either strain in artificial inoculations.

Series 8.-To determine the time required for the tomato and potato strain to infect the tissues of the potato plants a series of inoculations were made in which the plants were removed from the moist chamber at definite intervals. After removal from the moist chamber the plants were immediately taken to a warm room and the excess moisture on the foliage was dried off quickly by means of an electric fan.

\section{TABLE 5.-Time Required for Penetration and Infection On Potato} Plants.

\begin{tabular}{|c|c|c|c|c|c|c|}
\hline \multirow[b]{2}{*}{ Items Considered } & \multicolumn{6}{|c|}{ Time in Moist Chamber After Inoculation } \\
\hline & \multicolumn{2}{|c|}{$31 / 2$ Hours } & \multicolumn{2}{|c|}{6 Hours } & \multicolumn{2}{|c|}{24 Hours } \\
\hline Strains Used & $17 \mathrm{~T}^{*}$ & $18 \mathrm{P} \dot{\dagger}$ & $17 \mathrm{~T}^{*}$ & $18 \mathrm{P}^{\circ}$ & $17 \bar{T}^{*}$ & $\overline{18 \mathrm{P}} \dagger$ \\
\hline Number POTATO Plants & 16 & 16 & 16 & 16 & 16 & 16 \\
\hline Number Plants Infected & 0 & 2 & 0 & 11 & 16 & 16 \\
\hline Stems with Stem Lesions & 0 & 2 & 0 & 5 & 11 & 16 \\
\hline
\end{tabular}

*Tomato Strain from West Virginia.

-Potato Strain from Test Virginia. 


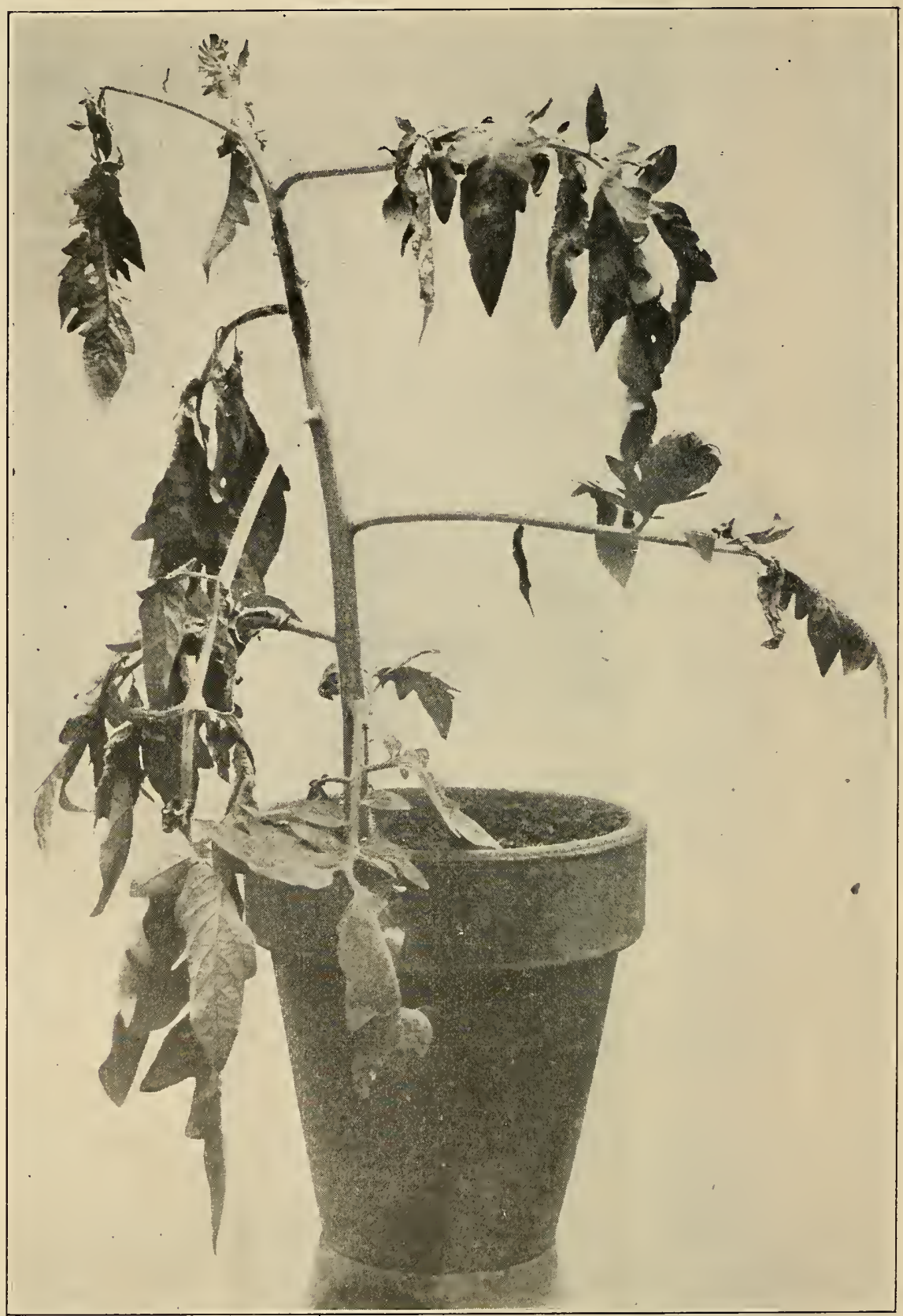

Fig. 6.-Tomato Plant Ten Days After Inoculation with Tomato Strain, Showing Stem, Leaf, and Petiole Infection. 
From these data, it appears that it takes a longer period of time for the tomato strain to penetrate the potato tissue and produce infection than it does for the potato.strain.

Series 9.-This inoculation is a duplicate of Series No. 8 with the exception that a potato strain from Maine was substituted for the West Virginia strain. The results are practically identical.

r.

TABLE 6.-Time Required for Penetration and Infection on Potato Plants.

\begin{tabular}{|c|c|c|c|c|c|c|}
\hline \multirow{2}{*}{ Items Considered } & \multicolumn{6}{|c|}{ Time in Moist Chamber After Inoculation } \\
\hline & \multicolumn{2}{|c|}{$3 \overline{1} / 2$ Hours } & \multicolumn{2}{|c|}{$53 / 4$ Hours } & \multicolumn{2}{|c|}{8 Hours } \\
\hline Number & $2 \mathrm{P}^{*}$ & $17 \mathrm{~T} \dagger$ & $2 \mathrm{P}^{*}$ & $\overline{17 \mathrm{~T} \dagger}$ & $2 \mathrm{P}^{*}$ & $17 \mathrm{~T} \dagger$ \\
\hline Number POTATO Plants & 12 & 12 & 12 & 12 & 12 & 12 \\
\hline Total Number of Stems. & 27 & 24 & 27 & 19 & 27 & 22 \\
\hline Number of Plants Infected & 3 & 0 & 12 & 1 & 12 & 4 \\
\hline Number of Stems Infected & 3 & 0 & 22 & 1 & 26 & 4 \\
\hline
\end{tabular}

* Potato strain from Maine.

†Tomato strain from West Virginia.

TABLE 7.-Time Required for Penetration and Infection on Tomato Plants.

\begin{tabular}{|c|c|c|c|c|c|c|c|c|}
\hline \multirow{2}{*}{ - Items Considered } & \multicolumn{8}{|c|}{ Time in Moist Chamber After Inoculation } \\
\hline & \multicolumn{2}{|c|}{$31 / 2$ Hours } & \multicolumn{2}{|c|}{$51 / 2$ Hours } & \multicolumn{2}{|c|}{9 Hours } & \multicolumn{2}{|c|}{24 Hours } \\
\hline Strain Number & $\mathrm{T}$ & $\mathrm{P}$ & $\mathrm{T}$ & $\mathrm{P}$ & $\mathrm{T}$ & $\mathrm{P}$ & $\mathbf{T}$ & $\mathrm{P}$ \\
\hline Number of TOMATO Plants & 6 & 6 & 6 & 6 & 6 & 6 & 6 & 6 \\
\hline Number of Plants Infected & 0 & 0 & 3 & 0 & 5 & 2 & 6 & 6 \\
\hline Plants with Stem Lesions .... & 0 & 0 & 3 & 0 & 4 & 0 & 6 & 0 \\
\hline
\end{tabular}

Series 10.--In this series, tomato plants were inoculated with the potato strain of $P$. infestans while potato plants were inoculated with a tomato strain of $P$. infestans. The plants were removed from the moist chamber at various intervals, and the excess moisture dried off by means of a fan. 


\section{TABLE 8.-Time Required for Penetration and Infection on To- mato Plants.}

\section{Items Considered}

\begin{tabular}{|c|c|c|c|c|c|c|c|c|}
\hline \multirow{2}{*}{ Items Considered } & \multicolumn{8}{|c|}{ Time in Moist Chamber After Inoculation } \\
\hline & \multicolumn{4}{|c|}{$31 / 2$ Hours $51 / 2$ Hours } & \multicolumn{2}{|c|}{9 Hours } & \multicolumn{2}{|c|}{24 Hours } \\
\hline$\overline{\operatorname{tra}}$ & $17 \mathrm{~T}$ & $2 P$ & $17 \mathrm{~T}$ & $2 \mathrm{P}$ & $17 \mathrm{~T}$ & $\overline{2 \mathrm{P}}$ & $17 \mathrm{~T}$ & $2 \bar{P}$ \\
\hline ATO P & 8 & 8 & 8 & 8 & 8 & 8 & 8 & $\overline{8}$ \\
\hline er of Plants Inf & 0 & 0 & 1 & 0 & 5 & $8 *$ & 8 & $8 \dagger$ \\
\hline Plants with Stem Lesions & 0 & 0 & 1 & 0 & 5 & 0 & 8 & 0 \\
\hline
\end{tabular}

*Few small spots on lower leaves.

$\dagger$ Numerous small spots on lower leaves.

It should be noted that in the nine hour interval, the number of tomato plants infected by the potato strain was greater than the number of plants infected by the tomato strain. However, the plants infected by the potato strain contained only a few small lesions on the very lower leaves.

Heavy infection on the upper foliage which is much more resistant to the potato strain, appeared only on the plants that were left in the chamber for twenty-four hours. In certain inoculation experiments for demonstration purposes where temperature conditions were too high for optimum germination of $P$. infestans spores, the potato strain sometimes infected only a few of the lower leaves or failed entirely and vice versa.

It is questionable whether the potato strain will infect tomato foliage in nature. By close observation in fields where the two plants were interplanted and the potato foliage heavily infected, no infections could be noted on the tomato foliage. Fields of tomatoes heavily infected were also observed in which intermingled potato plants were growing free from blight. It would appear, therefore, that the two strains are rather closely host adapted, and that a transfer from one host to the other takes place only under the most favorable conditions.

\section{TABLE 9.-Time Required for Penetration and Infection On Potato Plants.}

\begin{tabular}{|c|c|c|c|c|c|c|c|c|}
\hline \multirow{2}{*}{ Items Considered } & \multicolumn{8}{|c|}{ Time in Moist } \\
\hline & \multicolumn{2}{|l|}{3} & \multicolumn{2}{|c|}{$51 / 2$ Hours } & \multicolumn{2}{|c|}{9 Hours } & \multicolumn{2}{|c|}{24 Hours } \\
\hline Strain $\mathrm{Nu}$ & $17 \mathrm{~T}^{*}$ & $2 \mathrm{P} \dagger$ & $17 \mathrm{~T}^{*}$ & $2 \mathrm{P} \dagger$ & $17 \mathrm{~T}^{*}$ & $2 \mathrm{P} \dagger$ & $17 \mathrm{~T}^{*}$ & $2 \mathrm{P}_{\dagger}^{\dagger}$ \\
\hline PO POTATO P & 14 & 14 & 14 & 14 & 14 & 14 & & 14 \\
\hline er of Stems & & 38 & 32 & 3 & 36 & 48 & 32 & 48 \\
\hline ber of Stems In & 0 & 13 & 8 & 28 & 6 & 48 & 18 & 48 \\
\hline Number Lesions on Body & 0 & 8 & 0 & 18 & 9 & 46 & 2 & 48 \\
\hline
\end{tabular}




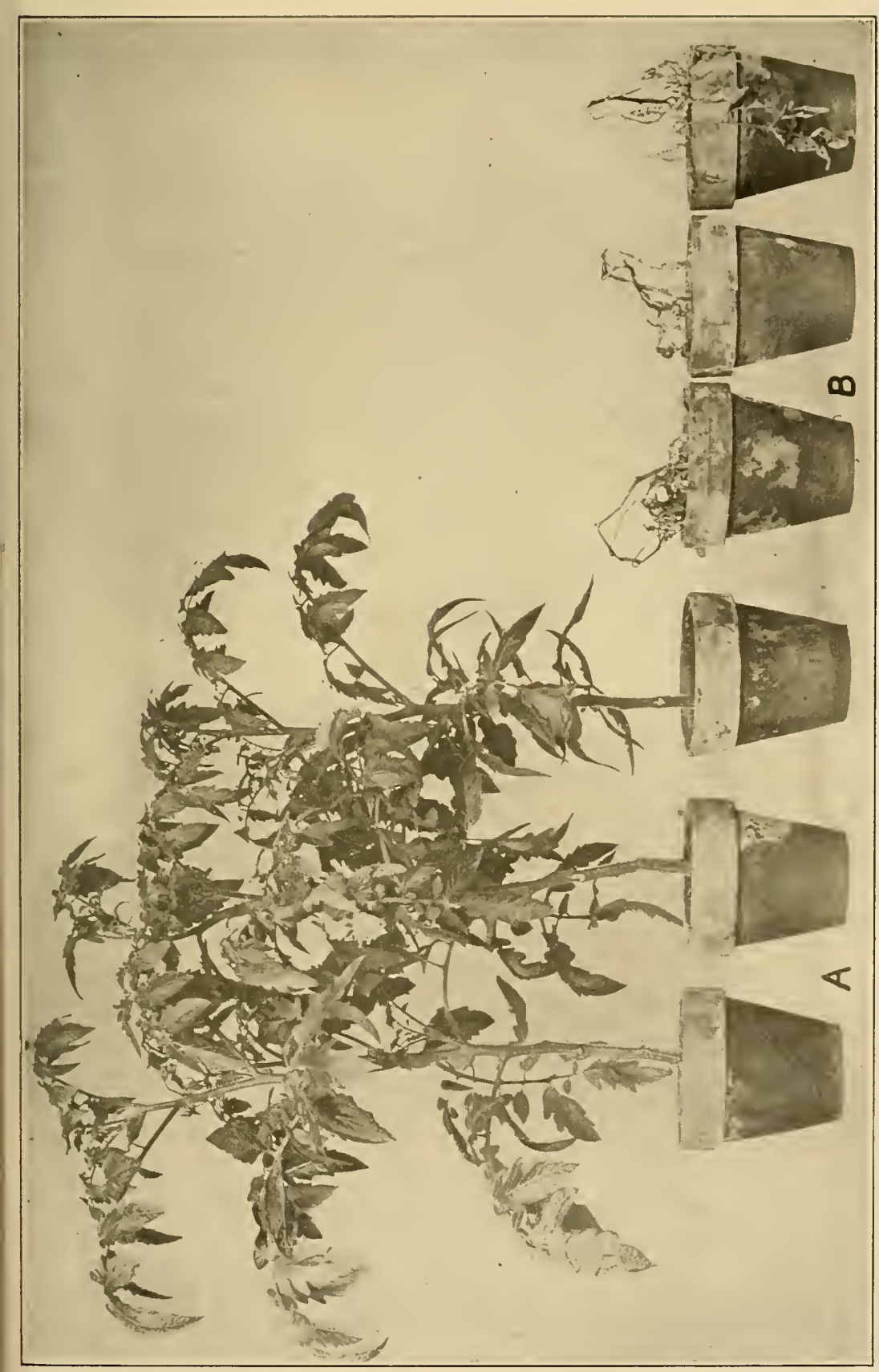

ํํㅇ

紊量

ō

$\stackrel{5}{*}=$

$\frac{0}{3}$

오름

竞

$=4$

$=$

…

is

ฮั

is $\propto$

논

त

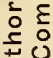

芒

응 은

艺

$\frac{c}{a} \geq$

둥

事

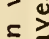

응

$\underset{\pi}{\pi}-$

उั

옹

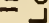

ذั

世

(4)

$x+$

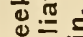

$3 \frac{\pi}{6}$

。号茄

○ 0

F

क उ ह

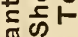

$\bar{a}=\stackrel{0}{2}$

$0 . \frac{\pi}{\pi}$

范紊士

○。

$1+$

1 䒕

No

호 
From the foregoing results it appears to take a longer interval of time for the potato strain to penetrate the tomato tissue and produce infection than it required for the tomato strain. On the other hand, the results given in Tables 5, 6 , and 8 indicate that it takes a longer period of time for the tomato strain to penetrate the tissues of the potato plant and produce infection than is required by the tomato strain. The number of potato stem infections produced by the tomato strain was appreciably less and the diseased lesions did not progress as rapidly as those produced by the potato strain. This has manifested itself in several inoculation experiments.

Series 11.-The object of this experiment was to test the degree of stability of the tomato and the potato strains of $P$. infestans. A tomato strain, 17T, isolated from a diseased tomato fruit collected at Davis, West Virginia, was grown on potato tubers for twelve months. It was transferred forty-nine times during this period. A potato strain, 18P, isolated from a diseased potato leaf, gathered in our pathological garden at Morgantown was carried for four months on tomato plugs cut from green tomato fruits. During this period it was transferred fifteen times. It was then transferred to young tomato stems sterilized by soaking in a solution of $1: 1000$ bichloride of mercury, rinsed in distilled water, then dipped into alcohol and flamed. The stems were then placed in sterile test tubes with a moist cotton plug in the bottom. The fungus was transferred into a slit into the side of the stem, as the potato strain will not grow on tomato stems unless inserted through the epidermis. After three transfers at intervals of two weeks each, the fungus growth became so weak that it had to be transferred back to the tomato plugs, on which it was grown six weeks longer, being transferred five times. The fungus was then transferred to halves of potato tubers to secure better growth and produce a sufficient quantity of sporangia to inoculate a number of plants.

TABLE 10.-Inoculation of Tomato Plants with Tomato and Potato Strains.

\begin{tabular}{l|c|c}
\hline \hline Strain Numbers & $17 \mathrm{~T}$ & $18 \mathrm{P}$ \\
Number TOMATO Plants & 43 & 40 \\
Number Plants Infected & $43 \dagger$ & 0 \\
Plants with Stem Lesions...-. & 43 & 0 \\
\hline \hline
\end{tabular}


TABLE 11.- Inoculation of Potato Plants with Tomato and Potato Strains.

\begin{tabular}{ll|l}
\hline Strain Numbers & $18 \mathrm{~T}^{*}$ & $18 \mathrm{P} \dot{\mathrm{i}}$ \\
Number POTATO Plants & 12 & 12 \\
Total Number of Stems & 22 \\
Number of Plants Infected & 12 \\
Stems with Stem Lesions & 16 & 26 \\
\hline
\end{tabular}

* Tomato strain from Davis, West Virginia.

$\div$ Potato strail from Morgantown, West Virginia.

The fact that a tomato strain could be grown for about one year on potato tissue with constant transferring on the arerage of once a week, and that a potato strain could be grown on tomato tissues for seven months and retain its original virulence, indicates that these strains possess considerable stability.

Series 12.- In this series we have a comparison between a tomato and a potato strain of the fungus, obtained from Australia, with a tomato and a potato strain isolated at Morgantown, West Virginia. It is remarkable to note that the same biological differentiation prevails in Australia as in America.

TABLE 12.-Comparison of Tomato Strains from Australia and from West Virginia on Tomato Plants.

\begin{tabular}{ll|l|l|l|c}
\hline \hline Strain Numbers & $11 \mathrm{~T}$ & $18 \mathrm{P}$ & $19 \mathrm{~T}$ & $7 \mathrm{P}$ \\
Number TOMATO Plants .-.- & 12 & 12 & 12 & 12 \\
Number Plants Infected..-- & $12 \dagger$ & $12 *$ & $12 \dagger$ & $12^{*}$ \\
Plants with Stem Lesions..-- & 12 & 0 & 12 & 0 \\
\hline
\end{tabular}

* Small lesions, mostly on lower leaves.

$\div$ Typical late blight lesions on leaves and stems.

TABLE 13.-Comparison of West Virginia Potato and Tomato Strains with Potato and Tomato Strains from Australia.

\begin{tabular}{l|l|l|l|l}
\hline Strain Number & $11 \mathrm{~T}^{*}$ & $18 \mathrm{P}^{* *}$ & $19 \mathrm{~T} \dagger$ & $7 \mathrm{P}^{\dagger}$ \\
Number POTATO Plants -.-- & 14 & 13 & 15 & 12 \\
Number of Stems - & 44 & 32 & 46 & 37 \\
Number of Plants Infected.--- & 10 & 13 & 16 & 12 \\
Number of Stems Infected -.-- & 16 & 32 & 20 & 37 \\
\hline
\end{tabular}

* Tomato strain from Morgantown, West Virginia.

* Potato strain from Morgantown, West Virginia.

† Tomato strain from Australia.

$\$$ Potato strain from Australia.

The Australian potato strain produced numerous small spots, mostly confined to the lower leaves, similar to the infection produced by the American potato strain. The Australian tomato strain produced typical 
late blight lesions on both leaves and stems of the tomato plants. These stem lesions, however, did not progress as rapidly as the one produced by American strains. This was noted in repeated inoculation tests.

Series 13.- In this inoculation experiment we have a number of strains from widely separated continents for comparative study.

TABLE 14.-Inoculation of Potato Plants with Potato and Tomato Strains from Five Different Countries.

\begin{tabular}{|c|c|c|c|c|c|c|c|}
\hline Strain Nu & $20 \mathrm{P}$ & $21 \mathrm{P}$ & $22 \mathrm{P}$ & $\overline{7 \mathrm{P}}$ & $\overline{19 T}$ & $23 \mathrm{P}$ & $\overline{24 T}$ \\
\hline Number POTATO Pl & 6 & 6 & 6 & 6 & 6 & 6 & 6 \\
\hline Required & 80 & 80 & 80 & 90 & 90 & 80 & 72 \\
\hline ected & 6 & 6 & 6 & 4 & 6 & .6 & 6 \\
\hline
\end{tabular}

\section{TABLE 15.-Inoculation of Tomato Plants with Potato and Tomato Strains from Five Different Countries.}

\begin{tabular}{|c|c|c|c|c|c|c|c|}
\hline Strain Number & $20 \mathrm{P}$ & $\overline{21 P}$ & $22 \mathrm{P}$ & $7 \mathrm{P}$ & $\overline{19 T}$ & $23 \mathrm{P}$ & $24 \mathrm{~T}$ \\
\hline Number TOMATO Plants & 6 & 6 & 6 & 6 & 6 & 6 & 6 \\
\hline Hours Required for Infection to Appear & 60 & 60 & 60 & 64 & 70 & 60 & 94 \\
\hline Number of Plants Infected & 6 & 6 & 6 & 6 & 6 & 6 & 6 \\
\hline Plants with Stem Lesions & 0 & 0 & 0 & 0 & 6 & 0 & 6 \\
\hline
\end{tabular}

The sources of the strains used in this series were as follows:

$20 \mathrm{P}$-Potato strain from Bermuda.

$21 \mathrm{P}$-Potato strain from Holland.

22 P-Potato strain from England.

$7 \mathrm{P}$-Potato strain from Australia.

$19 \mathrm{~T}$-Tomato strain from Australia.

$23 \mathrm{P}$-Potato strain from West Virginia.

24 T-Tomato strain from West Virginia.

It should be noted that a potato strain of $P$. infestans did not produce a stem lesion or a typical late blight lesion on the foliage of the tomato plants in any instance. In all cases, however, numerous small lesions were produced on the lower foliage with a gradual diminution in size and number towards the younger foliage. On the other hand, typical late blight lesions were obtained on both foliage and stems of all tomato plants inoculated with the American and Australian tomato strains. An accurate account was kept of the period of incubation required for the various strains. It should be noted that the period of incubation for the potato strain on tomato is shorter than that of the tomato strain on the same host plant, although as was shown in Series Nos. 8 and 9 , it takes a longer period of time for the potato strain to penetrate the tomato tissue and produce infection than is required for the tomato strain. 
Series 14.--To study further the relative pathogenieity of the tomato and the potato strains on potato, inoculations were made upon potato plants of the variety "Success" which has a rather resistant foliage.

TABLE 16.-Inoculation of Resistant Potato Plants with Tomato and Potato Strains.

\begin{tabular}{l|l|l}
\hline Strain Number & $11 \mathrm{~T}^{*}$ & $18 \mathrm{P}_{\dagger}^{\dagger}$ \\
Number POTATO Plants & 12 & 12 \\
Total Number of Stems & 21 & 12 \\
Number of Stems Infected & 1 & 9 \\
Stems with Stem Lesions & 0 & 9 \\
\hline
\end{tabular}

*Tomato strain from Morgantown, West Virginia.

$\uparrow$ Potato strain from Morgantown, West Virginia.

The fact that only one plant was infected by the tomato strain again indicates that this strain does not possess the same virulence on the potato plant as that possessed by the potato strain.

Series 15.-Green tomato fruits about half to two-thirds grown were inoculated by placing droplets of water containing a rich suspension of sporangia on the blossom ends of the fruits. Great care was taken to select fruits free from blemishes or bruises. The tomatoes were separated into two similar lots. One lot was inoculated with a potato strain and the other with a tomato strain. A plate from each lot was removed from the inoculation chamber at intervals as shown in Tables 17 and 18. The droplets containing the inoculum were removed by means of filter paper immediately after taking the fruits from the moist chamber.

TABLE 17.- Inoculation of Tomato Fruits with Potato and Tomato Strains and Infection with Different Lengths of Time in Inoculation Chamber.

\begin{tabular}{|c|c|c|c|c|c|c|c|c|c|c|c|}
\hline \multirow{2}{*}{\multicolumn{2}{|c|}{ Items Considered }} & \multicolumn{10}{|c|}{ Time in Moist Chamber After Inoculation } \\
\hline & & \multicolumn{2}{|c|}{$31 / 2$ Hours } & \multicolumn{2}{|c|}{5 Hours } & \multicolumn{2}{|c|}{8 Hours } & \multicolumn{2}{|c|}{10 Hours } & \multicolumn{2}{|c|}{24 Hours } \\
\hline Strain & Number & $26 \mathrm{P}^{*}$ & $27 \mathrm{~T} \dagger$ & $26 \mathrm{P}^{*}$ & $27 \mathrm{~T} \dagger$ & $26 \mathrm{P}^{*}$ & $27 \mathrm{~T} \dagger$ & $26 \mathrm{P}^{*}$ & $27 \mathrm{~T}$ & $26 \mathrm{P}^{*}$ & $27 \mathrm{~T}^{2}$ \\
\hline Number & TOMATO & & & & & & & & & & \\
\hline Fruits & s -------1 & 8 & 8 & 8 & 8 & 8 & 8 & 8 & 8 & 8 & 8 \\
\hline Number & of & & & & & & & & & & \\
\hline Fruits & Infected & 0 & 0 & 0 & 3 & 0 & 4 & 0 & 6 & 0 & 8 \\
\hline
\end{tabular}


TABLE 18.-Inoculation of Tomato Fruits with Potato and Tomato Strains and Infection with Different Lengths of Time in Inoculation Chamber.

\begin{tabular}{|c|c|c|c|c|c|c|c|c|c|c|}
\hline \multirow{2}{*}{ Items Considered } & \multicolumn{10}{|c|}{ Time in Moist Chamber After Inoculation } \\
\hline & $21 / 2 H$ & fours & $31 / 2$ & tours & $6 \mathrm{H}$ & urs & $10 \mathrm{H}$ & ours & $24 \mathrm{H}$ & Hours \\
\hline $\begin{array}{l}\text { Strain Num } \\
\text { Number To }\end{array}$ & $28 \mathrm{P}^{*}$ & $27 \mathrm{~T} \dagger$ & $28 \mathrm{P}^{*}$ & $27 \mathrm{~T} \dagger$ & $28 \mathrm{P}^{*}$ & $27 \mathrm{Tt}$ & $28 \mathrm{P} *$ & $27 \mathrm{~T}^{\dagger}$ & $28 \mathrm{P}^{*}$ & $27 \mathrm{~T} \dagger$ \\
\hline Fruits & 10 & 10 & 10 & 10 & 10 & 10 & 10 & 10 & 10 & -10 \\
\hline $\begin{array}{l}\text { Number of Frui } \\
\text { Infected }\end{array}$ & 0 & 0 & 0 & 1 & 0 & 5 & 0 & 7 & 0 & 10 \\
\hline
\end{tabular}

* Potato strain from Bermuda.

$\dagger$ Tomato strain from West Virginia.

Out of the 90 fruits inoculated with the potato strain not a single infection was noted. While the tomato strain in one case produced infection within a period of three and one-half hours after inoculation. The first signs of infection were noted five days after inoculation.

In another experiment sound, green tomato fruits were divided into three lots of twenty each. One lot of twenty tomatoes was inoculated on the uninjured surface with the tomato strain of $P$. infestans; another lot of twenty tomatoes was inoculated on the uninjured surface with the potato strain; and the third lot of twenty tomatoes was first wounded by means of numerous light pin pricks, and then similarly inoculated at the points of injury, with the potato strain. The method of inoculation was the same as deseribed for Series No. 15. All fruits were allowed to remain in the inoculation chamber for twenty-four hours. In four and one-half days the first signs of infection were noted on the wounded fruits inoculated with the potato strain. All fruits inoculated with the tomato strain showed signs of infection five days after inoculation. None of the sound fruits inoculated with the potato strain became infected. Tomato fruits do not have stomata. It is evident, therefore, that the potato strain is not capable of penetrating the cutinized epidermis of the tomato fruit. However, when the epidermis is ruptured, infection takes place. The diseased areas thus produced by potato strains of $P$. infestans enlarge at a much slower rate than those produced by a tomato strain. The resistance of tomato fruit to the invasion of the potato Phytophthora is to be explained not only by the inability of the fungus to gain entrance, but also by the presence of some resistant principle inherent in the tissues of the tomato.

\section{FIELD OBSERVATIONS}

The development of potato and tomato late blight in nature has been under observation by the writer for more than ten years. During this period, it has always been noted that the late blight of tomato makes its 
appearance from four to six weeks after the potato late blight. In instances where the early development of the blight was kept under close observation, the first signs of tomato blight were found on the plants adjacent to potato plants that were heavily infected with $P$. infestans.

In plots where tomatoes and potatoes were planted in alternate rows the potato plants sometimes became infeeted and completely died before any signs of infection could be noted on the tomato plants. It may be of interest to quote a passage from Dr. Brittlebank's* letter to Dr. Giddings in this connection: "Prior to the advent of $P$. infestans in our potato crop there was no record of tomato plants being affected, and we did not observe a case until the year following the first epidemic of late blight."

\section{STUDIES OF THE FUNGUS IN CULTURE}

In determining the $\mathrm{H}$-ion concentration of the extract of tomato fruits, leaves, and stems as well as that from potato tubers, stems, and leaves, it was found that the tomato extracts have a higher acidity than the potato extracts. This led to the belief that the difference in strains may perhaps be due to a higher acid tolerance of the tomato strain. Accordingly, a series of oatmeal agars with varying concentrations of eitric, lactic, and malic acids was prepared. The results obtained were not uniform enough to warrant any definite conclusions. It was found, however, that the tomato as well as the potato strain would grow on a medium of much higher acid content than that of the tomato fruit or stem extract.

Strains of $P$. infestans from tomato when transferred to raw potato tubers, will in most cases, grow as luxuriently as the fungus from potato on the same medium. It has been repeatedly observed, however, that the growth of the tomato strain is inhibited to a much greater extent than that of the potato strain when grown on tubers of blight resistant varieties, or tubers that have been in storage for a considerable time.

The potato strain can be cultured on blocks cut from green tomato fruits but the growth produced is less vigorous than that produced by the tomato strain when grown on raw potato blocks. The potato strain has a tendency to produce deformed and undersized sporangia when grown on tomato tissue.

The facts that the tomato strain can readily be transferred to potato tubers and the potato strain can be induced to infect tomato fruits when inoculated through the epidermis led several investigator's to believe that there was no biological specialization and that the fungus on potato readily passed over to the tomato plants in nature.

* The writer wishes to express his indektedness to Dr. C. Brittlebank, of Melbourne, Australia, for his prompt and splendid cooperation in furnishing us cultures of $P$. infestans, seeds of Solanum aviculare, and valuable information on the behavior of $P$. infestans in. Australia. 
Considerable divergence has been observed in the behavior of both the potato and the tomato strain in culture. Some cultures will go into a vegetative stage after being cultured for a short period of time, and fail to produce sporangia when transferred to raw potato blocks. Other cultures will consistently produce sporangia in profusion even after years of culture on artificial media. Sometimes a culture will lapse into a quiescent state for a period of time, producing only sparse growth, and then suddenly regain vigor and produce a very profuse growth.

Oospores.-Oospore-like bodies were first observed in 1919 in potato and tomato strains obtained from Australia. The fungus was cultured on raw potato tubers at that time. These bodies were produced in quantities and in several instances approached maturity although the majority disintegrated in a short time. Bodies of similar nature have been observed frequently since in other cultures. These bodies are formed in the aerial mycelial weft, but never in the potato tissue. The writer is inclined to believe that these bodies are abortive oospores which do not function in the life cycle of the fungus.

Mature oospores with well defined amphigenous antheridia have been found, occasionally in cultures grown on Quaker Oat media. Oospores do not seem to be produced with any degree of regularity. Cultures that produce oospores at one time may fail to do so under identical conditions at another time. Well defined oospores were never found in American cultures. The cultures in which oospores were produced were obtained from Australia, Holland, and England. The cultures that produced oospores were very vigorous growers and produced very few sporangia.

\section{SUMMARY}

1.-The $P$. infestans which produces late blight of tomato differs biologically from the form which produces potato blight. This has manifested itself in a large number of inoculation experiments.

Foreign strains of the fungus studied behave like American strains in this respect.

2.-The potato $P$. infestans will infect the tomato fruit and leaves under artificial conditions. The older leaves are most susceptible. On such leaves numerous small lesions are produced in which the fungus soon dies out and the plants fully recuperate. The tomato fruits could not be infected with this strain, unless by first rupturing the epidermis.

3.-The period of incubation for the potato strain, when inoculated on tomato plants, is shorter than that of the tomato strain on the same host and vice versa, in the forms studied.

4.- In all cases observed under natural conditions, potato late blight 
appeared earlier in the season than the tomato late blight and wherever tomato late blight was found potato late blight also occurred in close proximity.

\section{BIBLIOGRAPHY}

(1) APPEL, O.

1906. NEURE UNTERSUCHUNGEN UBER KARTOFFEL-UND TOMATEN-ERKRANKUNG. Sond. Jahrber. d. ver. d. Vertr. Agnew. Bot. III, 1906.

(2) ASHBY, S. F.

1917. ANNUAL REPORT OF THE MICROBIOLOGIST. 1916-1917.

Ann. Rept. Dept Agr. Jamaica, 1917: 26-28.

(3) BRIOSI, G.

1899. A REVIEW OF FUNGOUS DISEASES OBSERVED DURING 1897. Attic Inst. Bot. Univ. Pavia, 2 ser. 5: 327-352.

(4) BRITTLEBANK, C. C.

1919. TOMATO DISEASES. Jour. Dept. Agr. Victoria 17: 231-235 and 498-500.

(5)

1920. TOMATO DISEASES. Jour. Dept Agr. Victoria 18: 413-4i6.

(6) BUTLER, E. J.

1912. REPORT OF THE IMPERIAL MYCOLOGIST. Rept. Agr. Inst. and Col. Pusa (India) 1911-1912: 54-64.

(7) CARPENTER, C. W.

1917. REPORT OF THE DIVISION OF PLANT PATHOLOGY. Hawail Agr. Exp. Sta. Rept. 1917: 33-42.

(8) DARNELL-SMITH, G. P.

1921. DISEASES OF TOMATO SEEDLINGS. Agr. Gaz. N. S. Wales 32: 577.

(9) FINARDI, E.

1912. VEGETABLE PARASITES OF TOMATO. Avven. Agr. 20: 290292.

(10) GIDDINGS, N. J. and BERG, ANTHONY

1920. A COMPARISON OF THE LATE BLIGHT OF TOMATO AND POTATO. Phytopahtology 9: 209-210. 1 plate.

(11) GIRADI, J.

1917. TOMATO DISEASES. Rev. Min. Indus. Uruguay 5: 423-428.

(12) HERBERT, D. A.

1919. PATHOLOGICAL REPORT-WESTERN AUSTRALIA. Dept. Agr. and Indus. West Aust. Ann. Rept. 1919: 29.

(13) JEHLE, R. A., GOODMAN, J. W., and LINDLEY, J. W.

1919. CONTROL OF LATE BLIGHT OF TOMATOES IN THE BLUE RIDGE MOUNTAINS. Bul. N. C. Dept. Agr. 40: 3-16.

(14) JOHNSTON, T. HARVEY

1910. IRISH BLIGHT IN TOMATOES. Agr. Gaz. N. S. Wales 21: 563566 . 
(15) KERN, F. C. and ORTON, C. R.

1916. PHYTOPHTHORA INFESTANS ON TOMATOES. Phytopathology $6: 284-287$.

(16) MADARIAGA, A. and VILLARREAL, R.

1916. CONTROL OF PHYTOPHTHORA INFESTANS IN THE FLOATING GARDENS OF XOCHINNILCO. Bol. Dir. Agr. (Mex.) 2: 55-57.

(17) MARCHAL, E.

1901. IN BELGEN IM JAHRE 1901. BEOBACHTETE PILZ PARASITARE. Rapports sur les Maladies crytogamiques etudiets au Labaratoire de Botanique de l' Institut agricole de Gembloux 1901: 3-4.

(18) MANN, E. A.

1919. REPORT OF PLANT DISEASES. West Aust. Govt. Ann. Rept. 1919: 8 .

(19) MCALPINE, D.

1910-a. THE LATE BLIGHT IN TOMATOES. Jour. Dept. Agr. Victoria 8: $48-49$.

(20)

1910-b. SOME POINTS OF PRACTICAL IMPORTANCE IN CON. NECTION WITH THE LIFE-HISTORY STAGES OF PHYTOPHTHORA INFESTANS (MONT) DeBARRY. Annales Mycologici 8: 156-166.

1911. TOMATOES AND IRISH BLIGHT. Jour. Dept. Agr. Victoria 9: 379-382.

(22) MELHUS, I. E.

1916. INFECTION AND RESISTANCE STUDIES OF PHYTOPTHORA INFESTANS ON THE TOMATOES. Abs. in Phytopathology 6: 107.

(23) PAYEN, M.

1848. ON THE VEGETATION OF BOTRYTIS INFESTANS IN THE INTERIOR OF THE TOMATO. Gard. Chron. and Agr. Gaz. 1848: 6152.

(24) PLOWRIGHT, CHAS. B.

1881. ON THE FUNGOID DISEASES OF THE TOMATO. Gard. Chron. 16: $620-621$.

1884. TOMATO DISEASES. Gard. Chron. 22: 628.

(26) REED, H. S.

1912. DOES PHYTOPHTHORA INFESTANS CAUSE TOMATO BLIGHT? Phytopathology 2: 250-252.

(27) SMITH, RALPH E.

1906. TOMATO DISEASES IN CALIFORNIA. Cal. Agr. Exp. Sta. Bul. 175: 16.

(28) SMITH, W. E.

1881. DISEASES OF TOMATOES. Gard. Chron. 16: 346.

(29) STOCKDALE, F. A.

1915. REPORT ON PLANT DISEASE. (IN SUMMARY OF INVESTIGATIONS MADE DURING THE PERIOD JANUARY 1 TO JUNE 30, 1915). Mauritius Dept. Agr. 1915: 1-2. 
(30) STONE, G. E.

1911. DISEASES OF TOMATOES. Mass. Agr. Exp. Sta. Bul. 138: 13. and MONAHAN, N. F.

1906. ANNUAL REPORT, 1906. Mass. (Hatch) Agr. Exp. Sta. Ann. Rept. $1906 ; 115$.

(32) STURGIS, WM. C.

1893. COMMON FUNGOUS DISEASES AND THEIR TREATMENT. Conn. (New Haven) Agr. Exp. Sta. Bul. 115: 17.

(33) THAXTER, ROLAND

1890. REPORT OF THE MYCOLOGIST. Conn. (New Haven) Agr. Exp. Sta. Rept. 1590: 95.

(34) THOMAS, H. E.

1917. REPORT OF THE PLANT PATHOLOGIST. Porto Rico Agr. Exp. Sta. Rept. 1917: 28-30.

(35) WILTSHIRE, S. P.

1915. A NOTE ON PHYTOPHTHORA INFESTANS OCCURING ON TOMATOES. Univ. Bristol, An. Rept. Agr. and Hort. Res. Sta. 1915: $92-93$.

(36) ZACHAREWIZ, ED.

1889. TRAITMENT DE LA MALADIE DES POMMES DE TERRA, DES TOMATOES, ET DES MELONS PAR LES SELS DE CUIVRE. Le Progres Agricole et Viticole 14 Julliet, 1889. 



\section{HECKMAN}

BINDERY INC.

\section{JUNE 99}

N MANCHESTER INDIANA 46962 
